\title{
4
}

\section{Colonialism's and postcolonialism's fellow traveller: the collection, use and misuse of data on indigenous people}

\author{
lan Pool
}

\section{'Data sovereignty' $\rightarrow$ 'data suzerainty' $\rightarrow$ 'data sovereignty'}

Data sovereignty (DSov) is a somewhat narrow twenty-first-century concept from commercial law relating to the protection of digitalised individual, governmental and corporate information, and also to the safeguarding of the national security apparatus from nefarious actions. This chapter, using Aotearoa/New Zealand as a case study, extrapolates from this idea in several ways. DSov is defined here in a much broader way to include the notion of the supremacy of systems of data collection and use. It is essential to recognise that, before contact with imperial powers, indigenous peoples had their own vibrant, meaningful bodies of data, over which they had DSov. Art is one form of data storage - from cave paintings to the Benin bronzes in Berlin's ethnological museum. They show a chronological shift from African motifs to Portuguese soldiers after contact. The anonymous reviewer of this chapter pointed to another powerful example: the totem poles, which are data banks, of the tribes on the north-west coast of 
North America. Whakapapa (systematic information on genealogies) is an emblematic Aotearoa example of a culturally embedded data source to which I will return, as it has reappeared in the twenty-first-century data systems of Aotearoa's tribes (iwi).

Once colonialism occurred, however, indigenous peoples' data systems were replaced, at least in the public discourse, with those of the imperial metropoles and their settler colonists. The settlers' system thus gained data suzerainty (DSuz). This situation persisted into the postcolonial era, especially for those peoples who became 'indigenous minorities' in the territories over which they once ruled. For these people, internal colonialism was a reality of daily existence, even in nation-states that were avowedly liberal and relatively egalitarian; most typically, in the most benign polities, the needs of the politically and demographically hegemonic cultural groups will still prevail and, by accident or by design, indigenous people will not be consulted or their views will be ignored. The classical examples are infrastructure development or mining, which may be beneficial for the majority, but counter to the needs and wishes of an indigenous group; a road of 'national importance' may run the risk of destroying an indigenous burial site. Most extreme were systems such as South Africa's apartheid, where a minority malignly collected and used data on the majority to control their movements and daily lives. In post-apartheid South Africa, this has had perverse consequences: in a society riven by inequality that is still primarily a function of ethnicity, data on ethnic groups cannot be collected and thus analyses of health and other social inequalities are very difficult. ${ }^{1}$ Parastatal corporations - whose 'gold standard' is the East India Company (1765-1859) (Dalrymple 2015) - also exerted DSuz. Finally, before formal annexation, information becomes imperialism's 'fellow traveller', exemplified by hearings in Britain's House of Lords on precolonial New Zealand (British Parliamentary Papers 1838: vol. xxi).

I want, however, to recognise that the imposition of external data systems in both the colonial and the postcolonial eras is not restricted to settler societies, but occurs, as I will show, even in 'independent' postcolonial nations. It is a very significant issue whose import has not been sufficiently recognised. For either situation, when the colonising

1 Meeting, Statistical Bureau, Pretoria, May 2014; Meeting, Department of Demography, Cape Town University, June 2014. 
powers achieved DSuz over existing data systems, this was more than merely the displacement of one system by another. Instead, this process was reinforced - one might say strongly reinforced, in an attempt to expunge indigenous peoples' data from the public record-by the demonisation of native culture and technology. In the colonial era, indigenous peoples were seen as lesser 'races', at an inferior stage of social evolution, as evidenced in the eyes of Victorians by technology and data systems despite having data systems that allowed them to organise complex social and economic structures. In Aotearoa/New Zealand, Māori were seen as 'Stone Age savages' despite trading the length and breadth of the country. To colonists, by definition, any datasets that they themselves had not introduced and imposed were inferior, and thus of no utility for public policy analysis, dialogue and implementation.

Nevertheless, over the colonial period, many indigenous peoples nurtured culturally embedded data systems, with precolonial, typically precontact, provenance, but these rested virtually outside the purview of hegemonic majorities other than the social anthropologists and other researchers among them. Of course, the 'natives' were also frequently encouraged, or instructed, to resurrect some aspects of their culture to amuse tourists or visiting celebrities. The most common examples were dances or songs that constitute a form of memory bank for data, yet indigenous people were discouraged from applying these same data to illuminate issues arising in the public policy arena.

The majority population's imposition of DSuz - achieved by demonising indigenous people and denigrating the validity of their data systems - has had long-term consequences, which still affect the development of indigenous peoples' data systems today. Later sections of this chapter will address this problem. Taking an Aotearoa/New Zealand case study, I explore the backstory for twenty-first-century DSov issues facing indigenous peoples. For them, DSov is not merely a technical problem contingent on state-of-the-art computing; constraints on the generation of data systems by indigenous peoples are epistemological - a function of the unique history of data collection and use, and the wider historical context, in countries in which each indigenous group resides. The New Zealand case and similar backstories have left methodological chasms between indigenous 
peoples and the wider populations surrounding them. Other chapters in this book try to bridge this canyon and simultaneously address how the DSov of indigenous peoples can be protected.

Until recently, indigenous peoples' data needs have been mainly confined to social and cultural rather than commercial sectors, but as more indigenous groups establish corporations, business interests come into play. Even in the social sectors, well-developed state data systems - those on which some DSov debates focus - were foisted on 'precursor peoples' (Belich 2009:180), first by their colonisers and then by successor regimes. That said, ongoing development strategies require good knowledge bases, both for indigenous peoples and for the nation-states in which they live.

Once datasets are created, however, other DSov questions emerge (Scroggie 2013), as is true across the Western world (Venkatraman 2014). Conventionally, 'data sovereignty is the concept that information which has been converted and stored in binary digital form is subject to the laws of the country in which it is located' (see Snipp, this volume). Countries develop different regulatory instruments to enforce this narrowly defined form of DSov, but mainly for: 1) business and related financial demands, and 2) state and other security issues. This has been compounded by the Uniting and Strengthening America by Providing Appropriate Tools Required to Intercept and Obstruct Terrorism Act of 2001 (USA PATRIOT Act), the impacts of which spill into other jurisdictions. 'Clouds' seem especially difficult to protect (Young 2014).

For citizens in market economies, including indigenous people, personal data (for example, information on credit cards) are exported to, and stored in, foreign jurisdictions. The notion of DSov also invokes property rights and other values, which vary enormously between cultures. For example, Aotearoa's Native Lands Act (1865) trampled on these differences, eroding Māori wellbeing and embittering Māori-Pakeha (non-Māori) relations. In 1870, the Minister of Justice of the day made a statement that demonstrates superbly the sort of mindset Victorian colonists brought to evaluating Māori culture and its instruments such as data systems. He argued that the Land Act's function was 'to bring the vast bulk of lands ... within the reach of colonisation' - that is, it was imperative that land be made available for settlers by displacing Māori. He continued: 
The other great object was the detribalisation of the Māoris - to destroy, if it were possible, the spirit of communism which ran through the whole of their institutions ... It was hoped that by the individualisation of titles to land ... they would lose their communistic character. (Reproduced in Statistics NZ 1990: 414)

DSov is 'not often talked about in New Zealand' (Bennett 2013). Instead, New Zealanders focus more on free-trade agreements and protection of intellectual property, including, inter alia, knowledge about natural capital (for example, plants with possible medicinal qualities). These issues interpenetrate with those on cultural capital, both demanding guardianship (katiakitanga) and DSov. Nationally, concerns revolve around controls and interventions that might be exerted over nationstates - or, by extrapolation, over subpopulations-by powerful multinational corporations using extraterritorial tribunals biased towards corporate interests (Kelsey 2015). Conversely, globalisation's advocates have contrary concerns: All kinds of laws and regulations are conspiring to force managed service providers to manage data within the local jurisdictions of multiple countries' (Vizard 2014).

In the remainder of this chapter, I first examine how contact and colonialism accidentally submerged-or intentionally expungedindigenous peoples' extant epistemologies. This has profound implications for the acceptability of twenty-first-century indigenous peoples' data strategies - some with roots in the precontact period, some that adapt conventional techniques and others that hybridise these two. I am not a historicist, but here I am arguing that history has left very strong imprints on some contemporary data problems, especially those for which the ideational context is a key element in their genesis. Second, I review the processes for data collection and analysis over different phases of precolonialism, colonialism and postcolonialism. Finally, given these histories, what are the DSov implications of emerging methods and the information they produce: in sum, who controls what? 


\section{The historical context: demonising indigenous peoples}

Indigenous peoples have felt the force of colonialism's footprint: the past half-millennium's Euro-North American imperialism bequeathed us systematic denigration of intellectual infrastructures existing before contact and/or colonial control. Unfortunately, much of colonial history focuses on Euro-American expansion and the implantation of Western institutions, thereby implicitly endorsing Victorian imperialist notions of technical, governmental, administrative and moral superiority. Despite contrary historical evidence, these assumptions remained unchallenged until the mid-twentieth century, only to be reinvigorated by twenty-first-century revisionists (for example, Ferguson 2007).

Missionaries endorsed Britain's 'civilising mission' in Aotearoa. Literate, often diligent and compassionate people, they chronicled the conversion of Māori - an alternative to 'fatal impact' (see below) (Belich 1996:156). Subsequent writers often uncritically reify missionary accounts, although conventional history has been more even-handed. Most historians are selective, using English-language sources, but Jennings's (2011) research on 2,000 French Marian documents shows how biased are more commonly used accounts. These well-travelled, Māori-speaking brothers reported a low incidence of cannibalism, whereas for some other writers, it was a widespread 'practice' (Moon 2008).

For their colonising mission, imperialists imported data methodologies, smugly assuming that epistemologies other than Euro-North American ones were inferior. This view still haunts the wider society's acceptance of information systems now being generated by indigenous scholars. Today, many indigenous peoples challenge this, but they must fight powerful demons implanted, in Aotearoa's case, from first contact (1642) — which labelled Māori as 'murderers' and Australasians as 'opposite-footers' (antipodeans) - or from the first continuous interaction (1769). Victorians exaggerated, and even invented, lurid accounts of native life both before and after contact - myth-building that has uncritically fed into the writings of revisionists, who today are framing the prejudices of public officials who must evaluate and use indigenous peoples' data systems. To justify the subjugation 
of indigenous peoples, they were rated as 'noble savages', at best, 'untrustworthy sub-human brutes', at worst, lacking intricate social and economic systems and mores (Wright 2008). Comments on indigenous people were often self-contradictory, even within the one commentary - for example, they could argue that native population decline was determined both endogenously (their own fault) and exogenously ('fatal impacts' due to contact with 'superior peoples').

Aotearoa was not unique. In the Americas, Spanish explorers, 'pilgrim fathers' and postcolonial American writers alike denigrated the sophisticated agricultural and urban systems of Native America, yet plundered their food, perpetrated ethnic cleansing and re-demonised them in Hollywood westerns.

In 1867, Francis Parkman, America's popular historian ... wrote 'The Indians melted away not because civilization destroyed them, but because their own ferocity and intractable indolence made it impossible that they could exist in its presence.' (Wright 2008: 62)

To Spanish theologians:

The bleeding of the New World became an act of charity ... The Indians were used as beasts of burden because they could carry a greater weight than the delicate llama, and this proved that they were indeed beasts of burden. (Galeano 1973: 52-3)

Philosopher David Hume 'declined to recognize the "degraded men" of the New World as fellow humans' (Galeano 1973: 41). But let us remember that the English also denigrated their Celtic subjects: Water Babies author, the Reverend Charles Kingsley, called the recently famine-decimated Irish 'human chimpanzees', adding the mantra oftrepeated across the Empire: 'I believe there are not only more of them than of old, but they are happier, better, more comfortably fed under our rule than they ever were' (cited in Hechter 1975: xvvi-ii).

In Aotearoa, Dr Newman wrote solid, scientific papers on Pakeha longevity, but on Māori, he turned rabid polemicist (1882: 175-7):

I have made it clear that the Māoris were a disappearing race before we came here ... The disappearance of the race is scarcely subject for much regret. They are dying out in a quick and easy way and being replaced by a superior race. 
Reverend Wohlers, citing the 'groveling animalism' of Māori, concluded (1881: 132): 'I can positively say that the coming of the Europeans has nothing to do with the dying out of the race ... [who] had outlived their time.'

Victorian epistemologies were underpinned by racial theories. 'Polygenism' saw humanity divided into groups that were racially distinct - with European superiority a given (Belich 1986: 323 ff., 1996: 125-6). Paradoxically, Charles Darwin's work reinforced that mindset, appearing 'to offer an evolutionary justification for European colonialism' (Paxman 2011: 122). Anthropology and psychology spent decades looking for racial and eugenic differences between peoples, arguing in the late-nineteenth century that, facing contact with superior civilisations, natives lost the will to reproduce or adopted social pathologies that had a 'fatal impact' - a perspective that seemed oblivious to the role of childhood survival in population replacement. The 'clash of cultures' paradigm, elaborated by interwar Oceanic anthropologists (for example, Rivers 1922; Pitt-Rivers 1923; cf. Pool 1977: 75-9), persisted in Australia until after World War II (Price 1949) and also in New Zealand, even though 'impact' had not been 'fatal' for Māori-they survived as a people (Belich 1996: Ch. 7). Indeed, by World War II, rapid Māori growth deeply concerned neo-eugenicist H. (not K.) Sinclair (1944). Finally, after the war, 'modernisation' paradigms replenished more blatantly racist frameworks, seeing America as the prototypical modern, liberal, democratic marker - an iconic paper being 'Making men modern' (Inkeles 1969). 'Take-off' - highly desired in Rostow's schema (1960: 4-16)-required social engineering that 'shocked the traditional society and hastened its undoing' (1960: 6).

Unfortunately, flawed ideas die slowly, so this undercurrent persists: Australia's twenty-first-century 'history warriors', ${ }^{2}$ led by Keith Windschuttle and inspired by America's 'neocons', revitalised racism. Windschuttle virulently attacked New Zealand ethno-historian Anne

2 The movement was a reaction to eminent anthropologist 'Bill' Stanner, who lamented that Aborigines had been virtually ignored and Australia's history presented positively. One of the more extreme ideas of the 'John Howard intellectuals' - so named by Australia's former prime minister - was that settlers counterattacked Aborigines because of their unprovoked violence towards colonists. 'History warriors' also deny the repression and killing of Tasmanian Aborigines (Windschuttle 2002; cf. Attwood 2005). 
Salmond's (1997) use of early Māori sources, recorded in tribal 'books' . ${ }^{3}$ These were not reliable, Windschuttle argued, because Māori were barbarians:

At the time of contact with European explorers, the Māori were engaged in continual tribal warfare. One of [the] prizes was the killing and eating of opposing warriors. Cannibalism was rife throughout Māori communities, and, since they had exterminated all large animals ${ }^{4}$ and birds, human flesh constituted a major source of protein in the Māori diet. (Windschuttle 1997: 275)

Aotearoa's revisionists are more 'tabloid historians', lacking Australia's political impacts. Nevertheless, 'tabloidists' often draw uncritically on Victorian myth-building whereby Māori adopted, or inherited from prehistory, every social pathology except drug addiction. Presumably, opiates - the lifeline of middle-class ladies and aristocratic bohemians - were far too refined for 'brutish' Māori. 'Tabloidism' has, however, had two long-term negative effects. First, by focusing on the ephemeral, there is a major gap in the knowledge of the everyday social and economic lives of 'precursor peoples', of indigenously driven activities that continued after contact, often into the colonial era and beyond. Second, it has helped feed spurious ideas into the race relations discourse, and this affects how policymakers and politicians view ideas, including data systems, developed by Māori. Comments can be coded, such as those by former minister Michael Bassett (2003) that the 'poor should stop breeding'; openly prejudiced, such as Don Brash (2004), leader of the opposition National Party, attacking the privileges of Māori; or wrong, such as current Prime Minister, John Key, asserting against all historical evidence (2014) that 'New Zealand is one of the few countries that [was] settled peacefully'.

3 Māori oral history was documented by the middle of the nineteenth century by iwi (tribes), hapu (subtribes) and whānau (wider families) across Aotearoa and protected since as taonga (treasures). By about 1850, Māori alphabetisation levels exceeded those of Pakeha, yet the elders who preserved oral records were still alive and had been trained in specialised schools of advanced learning. The significance of oral traditions was confirmed by Judith Binney (2009:74): 'By the 1840s, orality - the recall and narration of history from memory - was being mediated by access to literacy for Māori men and women.' A great strength of Anne Salmond's work is that she is one of the rare Pakeha scholars who can read these 'books'. Māori scholar Bruce Biggs, in collaboration with scholars from other iwi, similarly used these records in his classic study, Mãori marriage (1960).

4 Tiny bats were Aotearoa's only land mammals; by contrast, sea mammals were abundant, but were not made extinct by Māori, whereas Pakeha extractive industries severely reduced numbers. 
At the time of editing this chapter, Brash published another comment that is highly apposite, on the issue of water rights. Appealing to the Treaty of Waitangi (1840), New Zealand's foundation constitutional document signed by chiefs from all over Aotearoa, Māori have called for consultation about allocation of water and comanagement with some local authorities. Brash (2016) sees this instead as a bid for water ownership, arguing:

[T] o suggest that Governor Hobson saw himself, on behalf of Queen Victoria, entering into a partnership with a number of chiefs, many of whom could neither read nor write, has to be a total nonsense, Lord Cooke [a New Zealand judge, and expert on Waitangi, on the Privy Council] notwithstanding.

Brash's argument misstates the treaty signing process and therefore the understandings of signatories as to what they were signing: there were two versions, both very short, one in Māori and one in English. While there is controversy about the translation into Māori, any 'unalphabetised' chief would still have been versed in a powerful oral tradition, so would have had no difficulty understanding the Māori version, and would have assumed it to reflect accurately what was in the English version.

\section{Empire building, postcolonialism, internal colonialism and data}

Conventional historians have documented the 'displacement' of indigenous populations by conquest or 'swamping' (outnumbering by settlers) during different phases of empire building (Belich 1996: 249, 2009: 21, 180-2). To displace and control indigenous people, imperialists required data-colonialism's almost universal fellow traveller. The Oxford English Dictionary defines 'colonialism' as 'the policy or practice of acquiring ... control over another country, occupying it with settlers, and exploiting it'. But, for indigenous peoples who are minorities, such controls have continued to the present through postcolonialism, neocolonialism and internal colonialism.

Independence also does not end the imposition of exotic data systemsneither for minority precursor peoples confronting demographically and politically hegemonic majorities nor for inhabitants of 'newly 
independent countries' ${ }^{5}$ If they are minorities, indigenous people live in postcolonial countries using data systems inherited from the former colonial power and primarily suiting the needs of the majority's elites, often drawn from the former metropole. Hopefully, as more and more indigenous people enter government and private sector management roles, they gain some say in the collection and use of data. But another issue in the twenty-first century is that data become more complex as Europeans and non-Europeans of other origins immigrate to a country, with their own needs, generating bewildering data definition problems. ${ }^{6}$

Indigenous minorities are still subject to 'internal colonialism', even in the twenty-first century (defined by Pool 2015). The position of indigenous peoples has parallels with the problems faced by fully independent postcolonial territories, which, in establishing data systems, will have been advised by international agencies. While advisers act neutrally in standardising data content, they still favour conventions of Euro-American provenance; in effect, this is neocolonialism in another guise. This is not hyperbole - for example, globally recommended national accounts conventions distort statistical series by failing to address the informal and subsistence sectors and nonremunerated family workforces, inter alia, underestimating women's contribution to the economy (Waring 1988). The new (post-2004) national transfer accounts methodologies show how flawed the resulting data have been: intrafamily transfers, many of which are nonmonetised, operate across all social sectors, outrunning interfamily (public, charity) transfers. If intrafamily transfers are undocumented, this significantly undercounts the real economy's transactions, even in highly developed countries, but particularly where principles of family obligation (whanaungatanga) are important - say, when parents, not a bank, help their children buy a house or provide afterschool care.

5 Indigenous minorities inhabit many countries and are treated with varying degrees of justice and equality. My chapter focuses on Australasia and North America, making side references to Latin America and elsewhere.

6 For example: the first Croatians in New Zealand were 'Austro-Hungarians', but became Yugoslavs, then Croatians; many groups of European origin have seen similar shifts. Today, 14 per cent of New Zealand's population is Māori; 10 per cent are Asians; another 8 per cent are from the Pacific; plus others from Africa, the Middle East and Latin America; in total, 39 per cent identify with a non-European ethnic group. Clearly, ethnic data collection is very complex in such a situation. 
Moreover, some indigenous people engage in economic transactions outside the monetised economy - a theme elaborated in Australian work on hybrid economies (Altman \& May 2011; Russell 2011).

\section{Processes of data collection}

Imperialists did not enter data deserts, but the existing systems they encountered typically did not fit their world view. Even today, nonAborigines fail to understand the 'indicators' Aborigines exploit to 'manage' remote outback Australia (Taylor 2008). Most extant standard methodologies across the world date from the Victorians, who were fascinated by science, with a passion for 'moral statistics', eclectic in compass and, as a by-product, counting natives they encountered. Although driven by benign curiosity, some applied metrics to pseudoscience. By contrast, Thomson's The story of New Zealand (1859: v.2, annexes) represents the best of this genre, vesting today's scholars with useful and relatively 'robust' data.

Our data paradigms survive from the development of state registration and censuses - remembering that parish records, underpinning property rights, begat vital registration. The first British RegistrarGeneral, Dr William Farr, promoted the 'healthy districts' movementbucolic England (or temperate-climate colonies) versus evil cities (Lewis-Faning 1930) - so mortality statistics were prioritised. Contact and colonialism exposed precursor peoples to new data systems, ranging from counts that had almost no manifest, immediate impactalthough downstream usage may have had major effects - through to imposed collections that involved disruptions and even coercion, with negative implications. At their best, colonial enumerations produced administrative data, providing us with some insight into the lives of ordinary indigenous people. Combined with other data sources, they ensure that 'historical demography is possible despite the scarcity of the sacrosanct forms of demographic data cherished by demographers' (Cordell 2010: 22). Moreover, demography's unconventional techniques applied to historical and other deficient data allow researchers to build skeletal estimates - of population growth, life tables (using indirect estimation), gross reproduction rates and similar basic informationwith some likelihood that they represent real trends (Pool 2015). In this 
context, historical analysis is not an academic luxury, as is evident from the highly applied research contributing to New Zealand's Waitangi Tribunals.

But colonial administrations also used data to control the 'natives'the 'colonial order and the creation of knowledge' (Ittmann et al. 2010). Counting permitted macro-level classification, including by caste and race, manifested in Aotearoa by a focus on 'half-castes', awkwardly categorised as 'living as Māori' or 'living as Pakeha' (Kukutai 2011, 2012). Classification underpinned social engineering, typically at a meso (community) or micro (family) level, often enforced by coercion (for example, in British Central Africa, burning the huts of subsistence-economy families unable to pay cash hut taxes, to force the men into indentured labour). The 'need for labor in a variety of forms shaped the [macro-]demographic agendas of colonial regimes', leading 'colonial states to try to alter the demographic regimes of African populations' (Cordell et al. 2010: 8).

\section{Indigenous peoples and data sovereignty}

The de-valorisation of precontact eras also relates to data modalities, even those being generated today. Indigenous groups are attempting to reform the 'colonial order's' knowledge systems, developing new 'unconventional techniques' of data collection and analysis, often grounded in their own cultural heritage. For example, iwi (tribal) registers in Aotearoa repackage data systems that go back at least to the first Māori arrivals (say, AD 1250), using whakapapa's oral knowledge base (genealogies) - resonant of parish registers used in demography's family reconstitution techniques. Whakapapa trace modern individuals to a distinguished ancestor and also link them with different hapu (subtribes), iwi and marae (sacred central area of a village). These data were not just fundamental to Māori cultural organisation; the socio-spatial connectedness of whakapapa was also instrumental for economic relationships governed by utu (commonly translated as revenge, more correctly reciprocity). ${ }^{7}$ Precontact Māori had highly developed, nonmonetised trading systems that extended

7 I thank ethno-historian Anne Salmond for generously making available to me unpublished manuscripts on nineteenth-century Māori ontology being prepared for a Marsden Research Grant. 
the length of New Zealand, often involving whakapapa-determined reciprocal obligations; their social and economic worlds were intimately integrated (Firth 1959). Importantly, today, whakapapa 'drill down' more deeply into that complex nexus than do modern methodologies other than specially commissioned, highly costly surveys. Nonetheless, like surveys, whakapapa have error properties: 'only certain lines of descent from key ancestors to living individuals and important marriage ties between ancestors at different generational levels are remembered and passed on' (Sissons et al. 1987: 149-50).

Indigenous minorities asserting their rights as actors in democratic societies exploit existing data systems. Negotiations with hegemonic groups need systems that are reconcilable with extant wider datasets for the population as a whole, becoming most critical when litigation occurs or entitlements are sought. To 'drill deep' for their own purposes, indigenous peoples may have to tailor their own methodologies, the specifications of which will be dictated by their specific needs. But residual attitudes, shaped by history, affect the way the wider society and the polity view data generated by indigenous peoples. Attacks on Waitangi Tribunal proceedings, which identify Crown failures to meet Treaty of Waitangi obligations, hinging on what was written there (in two different languages), show how deeply these prejudices may run.

To complicate matters, DSov invokes different levels of aggregation. Individually, if credit card details are lodged in another country, individuals risk losing sovereignty. At a meso-level, indigenous groups-whānau (wider family), hap $\bar{u}$ or iwi in Aotearoa-can legitimately claim DSov over their collective data, yet, in this day of data 'hoovering', the possibility of these collectivities losing real DSov exists, and can be exploited against the interests of indigenous groups: knowledge of the natural resources they rightfully control is a good example. At a macro-level, there is territory-wide DSov, when indigenous rights may not be safeguarded: if, under trade treaties, nations have not protected sovereign rights (or the rights of subgroups such as trade unions or iwi), international practice allows foreign countries or corporations to take offending parties to tribunals outside the jurisdiction in which indigenous peoples are domiciled. 
DSov practices vary between jurisdictions. But conventional usage is tangential to the wider problems facing indigenous peoples, for in this context it relates to regulating flows of digital data on Māori (or other indigenous peoples) to foreign jurisdictions. At present, public records data are restricted to digitalised - and anonymisedcontemporary data in New Zealand, and their historical equivalents will be available on public record only as tabulations. This is, however, merely one dimension of DSov, which opens up major intellectual property questions, not just for digitalised data. If hardcopy historical data are converted into portable formats (for example, photo-image) then that process allows their transfer offshore. As noted already, by the 1850s, many Māori hapū had written down whakapapa and other important cultural information. To date, their use has been restricted to hapu themselves and specialists (see Note 3) able to read Māori of that era. But one does not have to be a futurologist to see these data converted into photo-images, exported and translated. Lest this seems histrionic — much ado about nothing — some hapu 'books' contain information that has scientific or other properties, sovereignty and pecuniary values, all of which are disputed in cross-national trade negotiations under way at present (such as for the Trans-Pacific Partnership). The emotional and financial costs involved in the return of shrunken tattooed heads or meeting-house carvings and other items of cultural value to iwi in New Zealand are a portent of what might be involved. Moreover, such intellectual property could pass not just to other countries, but also into corporate hands outside public control; haka and moko (tattoo) designs have already.

\section{Towards a conclusion: opportunities, challenges, problems}

Indigenous peoples have a real window of opportunity, with no historical precedent, to achieve data sovereignty-an opportunity available because of the fortunate coincidence of a number of factors, some of which I have not covered above. First, there is clearly a desire on their part to take sovereignty over data, to protect their own rights; as individuals, all citizens want this, but here I am referring to indigenous peoples as collectivities, as identifiable subgroups (for example, iwi). Second, indigenous people have the intellectual 
and technical resources in their human capital to formulate and exploit such datasets (see, for example, FNIGC, Hudson et al., Hudson, Jansen, Yap \& Yu, this volume).

There are, however, challenges. The first is to win acceptance from their own people. But more difficult will be gaining validity in the wider community, entailing overcoming the residual imprints of historical demonisation and, for innovative methodologies, prejudices about the universal, technical superiority of Euro-American data systems. This is rendered more difficult today because data are a prime commodity in litigation as well as in research and scholarship.

Finally, there are exogenous problems. Hanging over the generation and use of knowledge is the spectre of data 'hoovering' by territorial and extraterritorial agencies and thus loss of DSov. Looking at a frontal view of a friend's house in the Cotswolds or checking an address seems a harmless use of Google. But what if those 'data' had greater economic, political or cultural significance or if my intentions were evil? What if uplifted data are patented or new parties gain DSuz over indigenous peoples' property rights without the knowledge of their original kaitiaki? And what if any new uses are malign or generate profits?

Indigenous peoples saw their DSov accede to DSuz under colonial and postcolonial regimes. They are on the cusp of regaining DSov for use in their own jurisdictions. It would be tragic if this metamorphosed instead into neo-DSuz under transnational corporate rule beyond the control of indigenous peoples or the polity in which they live.

\section{References}

Altman J \& May K (2011). Poverty alleviation in remote Indigenous Australia. In Minnerup G \& Solberg P (eds), First world, first nations: internal colonialism and Indigenous self-determination in northern Europe and Australia, Sussex Academic Press, Eastbourne, UK.

Attwood B (2005). Telling the truth about Aboriginal history, Allen \& Unwin, Sydney.

Bassett M (2003). Poor should stop breeding. Dominion Post, 30 September 2003. 
Belich J (1986). The New Zealand Wars and the Victorian interpretation of racial conflict, Auckland University Press, Auckland.

Belich J (1996). Making peoples: a history of the New Zealanders from first Polynesian settlement to the end of the 19th century, Allen Lane Penguin, Auckland.

Belich $\mathrm{J}$ (2009). Replenishing the earth: the settler revolution and the rise of the Anglo-world, Oxford University Press, Oxford.

Bennett B(2013). Data sovereignty in NZ, billbennett.co.nz/2013/07/05/ data-sovereignty-in-new-zealand/.

Biggs B (1960). Māori marriage, Reed for the Polynesian Society, Wellington.

Binney J (2009). History and memory: the wood of the whau tree, 1766-2005. In Byrnes G (ed.), The new Oxford history of New Zealand, Oxford University Press, Melbourne.

Brash D (2004). Nationhood, an address by Don Brash, leader of the National Party to the Orewa Rotary Club, Orewa, 27 January 2004.

Brash D (2016). Act of Parliament made water ownership clear. NZ Herald, 26 April 2016.

British Parliamentary Papers (1838), vol. xxi.

Cordell D (2010). African historical demography in the postmodern and postcolonial eras. In Ittmann K, Cordell D \& Maddox G (eds), The demographics of empire: the colonial order and the creation of knowledge, Ohio University Press, Athens, $\mathrm{OH}$.

Cordell D, Ittmann $K$ and Maddox G (2010). Counting subjects: demography and empire. In Ittmann K, Cordell D and Maddox G (eds), The demographics of empire: the colonial order and the creation of knowledge, Ohio University Press, Athens, $\mathrm{OH}$.

Dalrymple W (2015). The East India Company: the original corporate raiders. The Guardian, 4 March 2015, theguardian.com/world/2015/ mar/04/east-india-company-original-corporate-raiders.

Ferguson N (2007). Empire, Penguin, London. 
Firth R (1959). Economics of the New Zealand Māori, 2nd edn, Government Printer, Wellington.

Galeano E (1973). Open veins of Latin America: five centuries of the pillage of a continent, [English translation], Monthly Review Press, New York.

Hechter M (1975). Internal colonialism: the Celtic fringe in British national development, Routledge \& Kegan Paul, London.

Inkeles A (1969). Making men modern: on the causes and consequences of individual change in six developing countries. American Journal of Sociology 75(2):208-25.

Ittmann K, Cordell D \& Maddox G (eds) (2010). The demographics of empire: the colonial order and the creation of knowledge, Ohio University Press, Athens, $\mathrm{OH}$.

Jennings W (2011). The debate over 'kai tangata' (Māori cannibalism): New Zealand perspectives from the correspondence of the Marists. Journal of the Polynesian Society 120(2):129-47.

Kelsey J (2015). TPPA leak: Jacobi misleads about protections for NZ, itsourfuture.org.nz/tppa-leak-jacobi-misleads-about-protectionsfor-nz/.

Key J (2014). Radio interview, Te Hiku station, 20 November 2014, cited at stuff.co.nz/national/politics.

Kukutai T (2011). Māori demography in Aotearoa New Zealand fifty years on. New Zealand Population Review 37:45-64, Special Edition Festschrift to D Ian Pool (eds Kukutai T \& Jackson N).

Kukutai T (2012). Quantum Māori, Māori quantum: state constructions of Māori identities in the census, 1857/8-2006. In McClean R, Patterson B \& Swain D (eds), Counting stories, moving ethnicities: studies from Aotearoa New Zealand, Faculty of Arts and Social Sciences, University of Waikato, Hamilton.

Lewis-Faning E (1930). A survey of the mortality in Dr Farr's 63 healthy districts of England and Wales during the period 18511925. Journal of Hygiene [London] 30(2):121-53. 
Moon $\mathrm{P}$ (2008). This horrid practice: the myth and reality of traditional Māori cannibalism, Penguin, Auckland.

Newman A (1882). A study of the causes leading to the extinction of the Māori. Transactions and Proceedings of the New Zealand Institute 14:59-77.

Paxman J (2011). Empire: what ruling the world did to the British, Viking, London.

Pitt-Rivers G [Henry Lane-Fox] (1923). The clash of cultures and the contact of races: an anthropological and psychological study of racial adaptation, with special reference to the depopulation of the Pacific, Routledge \& Sons Ltd, London.

Pool I (1977). The Māori population of New Zealand, 1769-1971, Auckland University Press, Auckland.

Pool I (2015). Colonisation and development in New Zealand between 1769 and 1900: the 'seeds of Rangiatea', Springer, Cham, Switzerland.

Price A G (1949). White settlers and native peoples, Georgian House, Melbourne.

Rivers WHR (1922). The psychological factor. In Rivers WHR (ed.), Essays on the depopulation of Melanesia, Cambridge University Press, Cambridge.

Rostow W (1960). The stages of economic growth: a non-communist manifesto, Cambridge University Press, Cambridge.

Russell S (2011). The hybrid economy topic guide, Centre for Aboriginal Economic Policy Research, The Australian National University, Canberra, caepr.anu.edu.au/others/Other-1306975222.php.

Salmond A (1997). Between two worlds: early exchanges between Māori and Europeans, Viking, Auckland.

Scroggie C (2013). The clouded issue of data sovereignty, $A B C$ Technology and Games, 1 October 2013, abc.net.au/technology/ articles/2013/10/01/3859628.htm.

Sinclair H (1944). Population: New Zealand's problem, Gordon \& Gotch, Dunedin. 
Sissons J, Wi Hongi W \& Hohepa P (1987). The Puriri trees are laughing: a political history of the Ngapuhi in the inland Bay of Islands, Polynesian Society, Auckland.

Statistics NZ (1990). NZ official year book, Statistics NZ, Wellington.

Taylor J (2008). Indigenous peoples and indicators of well-being: Australian perspectives on United Nations global frameworks. Social Indicators Research 87:111-26.

Thomson AS (1859). The story of New Zealand: past and present, savage and civilized, 2 vols, John Murray, London.

Venkatraman A (2014). Cloud providers rush to build European datacentres over data sovereignty, ComputerWeekly.com, 27 October 2014, computerweekly.com/news/2240233331/Cloud-providers-rush -to-build-European-datacentres-over-data-sovereignty.

Vizard M (2014). Rising to the data sovereignty challenge, MSPmentor, 11 December 2014.

Waring M (1988). If women counted: a new feminist economics, Macmillan, London.

Windschuttle K (1997). Killing history: how literary critics and social theorists are murdering our past, Macleay Press, Sydney [republished by Free Press, New York].

Windschuttle K (2002). The fabrication of Australian history. Volume 1: van Diemen's Land, 1803-47, Macleay Press, Sydney.

Wohlers J (1881). On the conversion and civilization of the Māoris of the South Island of New Zealand, Transactions and Proceedings of the New Zealand Institute 14:123-34.

Wright R (2008). What is America? A short history of the new world order, Text Publishing, Melbourne.

Young B (2014). Data protection fears vs US cloud market, Information Week, 5 February, informationweek.com/government/ cloud-computing/data-protection-fears-vs-us-cloud-market/d/did/1234862. 
This text is taken from Indigenous Data Sovereignty: Toward an agenda, edited by Tahu Kukutai and John Taylor, published 2016 by ANU Press, The Australian National University, Canberra, Australia. 